\title{
Determination of buffering capacity of selected fermented feedstuffs and the effect of dietary acid-base status on ruminal fluid pH
}

\author{
Lukáš Bujňák, Iveta Maskal'ová, Vladimír Vajda \\ Department of Nutrition, Dietetics and Animal Breeding, University of Veterinary Medicine and Pharmacy, \\ Košice, Slovak Republic
}

Received March 3, 2010

Accepted April 6, 2011

\begin{abstract}
The aim of this study was to evaluate the buffering capacity of some fermented feedstuffs and the effect of dietary acid-base status on ruminal fluid $\mathrm{pH}$. The first experiment was performed with different types $(n=24)$ of wet and dry fermented feedstuffs to determine the buffering capacity and buffer value index. The buffer value index of wet corn silages was more negative than for dry corn silages account on acid loss during drying. In the second experiment, the effects of different concentrations of lactic acid on base-buffering capacity, buffer value index and indicators of fermentation process were studied in two groups of corn silages $(n=21)$. Two groups of analyzed values were compared using unpaired $t$-test. Differences among the groups in base-buffering capacity $(P<0.001)$ and buffer value index $(P<0.01)$ were significant. In the third experiment, rumen fluid $\mathrm{pH}$ was measured using 8 total mixed rations on 48 lactating dairy cows. In the present study no significant $(P>0.05)$ correlation was found between ruminal $\mathrm{pH}$ and dietary buffer value index. These results confirmed that dietary acid-base status alone is not adequate as a predictor of the need for buffers in the diet of lactating cows. It is the first report about using of buffering capacity determination methods for evaluation of feedstuffs and dietary acid-base status in dairy cows.
\end{abstract}

Buffer, ruminal $\mathrm{pH}$, silages, total mixed rations

The cow has three primary means of buffering acid ingested from silage or acid produced by rumen fermentation. These include buffer naturally occurring in saliva, buffering capacity of ingested feed and added dietary buffers. Buffers in dairy rations are compounds that neutralize excess acid within the ruminant's digestive system and help to resist changes in rumen $\mathrm{pH}$ when high grain or fermented forage are fed. They supplement the cow's natural buffers that occur in saliva. Ruminants are generally able to maintain ruminal $\mathrm{pH}$ within physiological limits by their own regulation of intake, endogenous buffer production, microbial adaptation and volatile fatty acids (VFA) absorption.

Buffering capacity $(\mathrm{BC})$ of forages can be defined as the degree to which forage material resists changes in $\mathrm{pH}$. All forages have different buffering capacities. Fresh forage with a high buffering capacity will require more acid to reduce its $\mathrm{pH}$ than forage with a low buffering capacity. Moharrery (2007) reported that BC in forage and protein concentrate are 5.6 and 4.1 times higher than $\mathrm{BC}$ in grains. Buffer value index (BVI) is related directly to BC but inversely to $\mathrm{H}^{+}$(acidity) (Tucker 1992). Feedstuffs influence the ruminal acid-base status through their $\mathrm{pH}, \mathrm{BC}$ and stimulation of salivation (Le Ruyet et al. 1992). The buffer value index can account for alterations in both of measures $(\mathrm{pH}, \mathrm{BC})$ and it provides a more complete evaluation of diet-induced changes in ruminal acid-base status.

The aim of the study was firstly to find base-buffering capacity and buffer value index of some fermented feedstuffs and investigate the effect of dietary base-BC and BVI on fermentation indicators of corn silages. The second aim was to find a relation among the total dietary BVI and dietary carbohydrate composition and ruminal fluid $\mathrm{pH}$.

Address for correspondence:

Lukáš Bujňák

Department of Nutrition, Dietetics and Animal Breeding

University of Veterinary Medicine and Pharmacy

E-mail: bujnak@uvm.sk

Komenského 73, 04181 Košice, Slovak Republic

http://www.vfu.cz/acta-vet/actavet.htm 


\section{Materials and Methods}

Feedstuffs and animals

In the first experiment, 12 samples of common wet fermented feeds (silages) and 12 samples of dried silages were analyzed for base-BC and BVI. Twenty-one samples of fresh corn silages with known base-BC, BVI and with different concentrations of lactic acid in dry matter (DM) of silage were used in the second experiment. Eight total mixed rations (TMR) for lactating dairy cows (40 to 60 days after calving) containing 30-50\% concentrate, were analyzed in the third experiment. The acid-base BC and BVI were measured for each of the 8 experimental rations separately. Samples of rumen fluid were obtained from 48 dairy cows from 8 herds of dairy cows (6 cows from each heard) and analysed for $\mathrm{pH}$ ( $\mathrm{pH}$ meter Consort C830, Belgium). Ruminal fluid samples were collected using a ruminal tube $4 \mathrm{~h}$ after feeding.

Analytical methods

The buffering capacity was defined as the resistance to change in $\mathrm{pH}$ from initial $\mathrm{pH}$ to 7 for silages and from $\mathrm{pH} 5$ to 7 for TMR. In order to prepare samples for BC determination, individual TMR were dried and ground to pass through 1-mm screen. The BC of fresh fermented feedstuffs was determined with a wet sample at an amount equivalent to $0.5 \mathrm{~g}$ of DM. For dry corn silages and TMRs, $0.5 \mathrm{~g}$ of dry matter (DM) mixed with $30-\mathrm{ml}$ of distilled, deionized water. The initial $\mathrm{pH}$ of feed was recorded after $3 \mathrm{~min}$ of equilibration. Buffering capacity was determined by titrating the $30-\mathrm{ml}$ solution under continuous stirring from its initial $\mathrm{pH}$ to $\mathrm{pH}$ of 5 with $1 \mathrm{~N} \mathrm{HCl}$ and by titrating a similar prepared solution of feedstuff from its initial $\mathrm{pH}$ to $\mathrm{pH}$ of 7 with $1 \mathrm{~N} \mathrm{NaOH}$. Thus, BC expresses the amount of acid or base required to produce a unit change in $\mathrm{pH}$ of a feed sample.

Buffering capacity was measured for TMR by the modified method of Moharrery (2007) and converted to milliequivalents per litre (meq $1^{-1}$ ) as follows: bBC (base-buffering capacity) $=($ millilitre of $1 \mathrm{~N} \mathrm{NaOH}) \times 10^{3} /$ 30 ; aBC (acid-buffering capacity) $=($ millilitre of $1 \mathrm{~N} \mathrm{HCl}) \times 10^{3} / 30$. The acid-base buffering capacity is defined as a sum of acid-BC and base-BC. Acid-Base Buffering Capacity $(\mathrm{abBC})=\mathrm{aBC}+\mathrm{bBC}$. For silages: If the initial $\mathrm{pH}$ was lower than 5 , only the volume of hydroxide required to increase the $\mathrm{pH}$ from initial $\mathrm{pH}$ to 7 was used to equation: $\mathrm{bBC}$ (base-buffering capacity $)=($ millilitre of $1 \mathrm{~N} \mathrm{NaOH}) \times 10^{3} / 30$. The BVI was calculated according to the formula of Tucker et al. (1992).

Diets were analyzed for dry mater (DM), crude protein (CP), ether extract (EE) and ash by the AOAC (2001). Neutral detergent fibre (NDF) and acid detergent fibre (ADF) were determined by procedures outlined by Van Soest et al. (1991). Non-fibre carbohydrates (NFC) were calculated using equations: $N F C=100-(N D F+C P+E E$ + ash) (NRC 2001). Determination of fermenting acids in silage was carried out in a two-capillary isotachophoretic analyser EA100 (VILLA LABECO, Slovak Republic). The acidity of the water extract (AWE) was determined by alkalimetric titration to $\mathrm{pH} 8.5$.

Statistical analysis

Parameters of regression lines and unpaired $t$-test were used. Correlation was calculated between rumen fluid $\mathrm{pH}$ and NDF, ADF, NFC and CP content of the diets. Unpaired $t$-test was used for comparing analyzed BC and BVI with different concentrations of acids in silage. Non-significant differences were defined at $P \geq 0.05$.

\section{Results}

\section{First experiment}

Initial $\mathrm{pH}$ of feedstuffs, analyzed base-BC and BVI are presented in Table1. The fermented feedstuffs have negative BVI and the most negative BVI was found for wet corn silages. In the present study $\mathrm{BC}$ was negative and significantly $(P<0.0001)$ correlated with initial $\mathrm{pH}$ $(\mathrm{r}=-0.726, \mathrm{n}=24)$. The BVI positively correlated with initial $\mathrm{pH}(\mathrm{r}=0.923, P<0.0001)$.

Table 1. Buffering capacity and buffer value index of selected fermented feedstuffs

\begin{tabular}{llcrc}
\hline & & Initial $\mathrm{pH}$ & base-BC & $\mathrm{BVI}^{2}$ \\
\hline Corn silage (wet) & $(\mathrm{n}=6)$ & $3.83 \pm 0.20^{3}$ & $16.84 \pm 2.92$ & $-1526.25 \pm 698.53$ \\
Corn silage (dry) & $(\mathrm{n}=6)$ & $3.97 \pm 0.19$ & $8.47 \pm 2.06$ & $-1063.76 \pm 476.46$ \\
Alfalfa silage (wet) & $(\mathrm{n}=6)$ & $4.56 \pm 0.19$ & $9.83 \pm 1.27$ & $-194.68 \pm 114.37$ \\
Alfalfa silage (dry) & $(\mathrm{n}=6)$ & $4.71 \pm 0.19$ & $5.19 \pm 0.47$ & $-109.77 \pm 85.16$ \\
\hline
\end{tabular}

${ }^{1} \mathrm{BC}\left(\right.$ meq $\left.\cdot 1^{-1}\right)$ - buffering capacity , ${ }^{2} \mathrm{BVI}$ - buffer value index, ${ }^{3} \mathrm{x} \pm \mathrm{SD}$

In this regard, reaction of the fermented feedstuffs in relation to the sodium hydroxide addition, the determination of buffering capacity was titration of a 30-ml aliquot from its original $\mathrm{pH}$ to $\mathrm{pH} 7$ with $1 \mathrm{~N} \mathrm{NaOH}$. Lactic acid and volatile fatty acids that were produced during ensiling affect the consumption of $1 \mathrm{~N} \mathrm{NaOH}$ solution for neutralizing samples. 
Comparison shows different alkaline solution consumptions for fresh and oven dry corn silages. Wet corn silage needed more $1 \mathrm{~N} \mathrm{NaOH}$ solution to neutralize the $\mathrm{pH}$ level of 7 due to acid loss during drying. The higher consumption of $1 \mathrm{~N} \mathrm{NaOH}$ solution corn silages compared to alfalfa silages is probably due to higher acid production during ensiling. Generally, consumption of hydroxide in wet corn silages is $1.2-3.9 \times$ higher than in wet alfalfa silages.

\section{Second experiment}

Corn silages used in the experiment were divided into two groups according to the amount of lactic acid in DM of silage (lactic acid $<80 \mathrm{~g} \cdot \mathrm{kg}^{-1} \mathrm{DM}$ in group 1, lactic acid $>80 \mathrm{~g} \cdot \mathrm{kg}^{-1}$ $\mathrm{DM}$ in group 2). Chemical characteristics of the fermentation process quality in silage used in the experiment are shown in Table 2. There were no significant differences in the dry matter of silages between groups. In group 1 we determined a lower value of base-BC compared to group 2 (Table 2). The sum of acids as well as the total content of lactic acid corresponded with the value of base-buffering capacity. The sum of acids in the silages was calculated as total amount of lactic acid and acetic acid. The correlation between the base$\mathrm{BC}$ value and the content of lactic acid in the DM of silages was significant $(\mathrm{r}=0.784)$. The buffering capacity was highly correlated $(\mathrm{r}=0.8)$ with total acid concentrations, too. Higher negative BVI was found in group 2 and negative correlation was found between BVI and the content of lactic acid $(\mathrm{r}=-0.655)$. Significant differences were observed between groups 1 and 2 in base-BC $(P<0.001)$ and BVI $(P<0.01)$. The active acidity value $(\mathrm{pH})$ of group 1 was significantly higher compared to the values of group 2 . Significant difference $(P<0.001)$ in the $\mathrm{pH}$ value was found among groups. Lower $\mathrm{pH}$ value of the silage is related to the lactic acid content and to the total acid content in the dry matter. Titration acidity of the water extract observed in group 1 was lower than in group 2. No significant difference in the AWE value was found between the groups.

Table 2. Chemical characteristics of the fermentation process in two different silages

\begin{tabular}{lcccr}
\hline & & $\begin{array}{c}\text { Group 1 }(\mathrm{n}=10) \\
\text { Total }(\mathrm{n}=21)\end{array}$ & $\begin{array}{c}\text { Group 2 }(\mathrm{n}=11) \\
\mathrm{LA}^{1}<80 \mathrm{~g} \cdot \mathrm{kg}^{-1} \mathrm{DM}\end{array}$ & $P$ value \\
\hline Lactic acid $\left(\mathrm{g} \cdot \mathrm{kg}^{-1} \mathrm{DM}\right)$ & $85.60 \pm 29.40^{8}$ & $59.47 \pm 14.00$ & $109.35 \pm 15.79$ & \\
Dry matter $(\%)$ & $33.46 \pm 4.94$ & $35.06 \pm 6.15$ & $32.00 \pm 3.16$ & $\mathrm{NS}^{7}$ \\
BaseBC $^{2}\left(\mathrm{meq} \cdot \mathrm{l}^{-1}\right)$ & $15.93 \pm 2.73$ & $13.94 \pm 1.94$ & $17.74 \pm 2.00$ & $<0.001$ \\
$\mathrm{BVI}^{3}$ & $-1628.92 \pm 498.03$ & $-1311.95 \pm 420.44$ & $-1917.07 \pm 381.00$ & $<0.01$ \\
$\mathrm{pH}$ & $3.80 \pm 0.16$ & $3.91 \pm 0.15$ & $3.69 \pm 0.09$ & $<0.001$ \\
$\mathrm{AWE}^{4}(\mathrm{mg} \mathrm{KOH} / 100 \mathrm{~g})$ & $2035.46 \pm 463.06$ & $1861.73 \pm 322.55$ & $2193.39 \pm 526.87$ & $\mathrm{NS}$ \\
Acetic $\mathrm{acid}\left(\mathrm{g} \cdot \mathrm{kg}^{-1} \mathrm{DM}\right)$ & $23.60 \pm 9.56$ & $25.04 \pm 11.08$ & $22.29 \pm 8.26$ & \\
$\Sigma$ acids $^{5}\left(\mathrm{~g} \cdot \mathrm{kg}^{-1} \mathrm{DM}\right)$ & $109.20 \pm 29.77$ & $84.52 \pm 17.51$ & $131.63 \pm 18.28$ & \\
\hline
\end{tabular}

${ }^{1} \mathrm{LA}$ - lactic acid; ${ }^{2}$ base BC - base buffering capacity; ${ }^{3} \mathrm{BVI}$ - buffer value index; ${ }^{4} \mathrm{AWE}$ - titration acidity of the water extract $\mathrm{mg} \mathrm{KOH} / 100 \mathrm{~g}$ of silage $;{ }^{5} \Sigma$ acids - lactic acid + acetic acid; ${ }^{7} \mathrm{NS}=$ Non significant $(P \geq 0.05) ;{ }^{8} \mathrm{x} \pm \mathrm{SD}$

\section{Third experiment}

The acid-base BC of TMRs fed to dairy cows varies from 3.44 to $4.43 \mathrm{meq} \cdot \mathrm{l}^{-1}$. Diet compositions and values for dietary BVI, AD, NDF and NFC that were fed to the dairy lactating cows from 8 herds (6 cows from each heard) are presented in Table 3 . Rumen $\mathrm{pH}$ ranged from $6.19 \pm 0.20$ to $6.39 \pm 0.44$ and declined in response to increased percentage of NFC $(r=0.642)$ in the rations but was not influenced by CP. Variations in dosage of the concentrate $(30-50 \%)$ feed affected the content of non-fibre carbohydrates $(33.50-$ $40.02 \%$ ). The dietary NFC : NDF ratio varied from $1.29: 1$ to $0.82: 1$ and affected rumen $\mathrm{pH}$. The correlation between analyzed dietary nonfibre carbohydrates and ruminal fluid $\mathrm{pH}(0.642)$ showed a slightly stronger relationship as seen for dietary buffer value index 
Table 3. Composition of 8 different total mixed rations (A-H) used for dairy cows

\begin{tabular}{|c|c|c|c|c|c|c|c|c|}
\hline Composition $^{1}$ & $\mathrm{~A}^{3}$ & $\mathrm{~B}$ & $\mathrm{C}$ & $\mathrm{D}$ & $\mathrm{E}$ & $\mathrm{F}$ & G & $\mathrm{H}$ \\
\hline $\operatorname{ADF}(\%)$ & 17.98 & 19.87 & 20.54 & 22.49 & 23.24 & 23.57 & 23.91 & 25.43 \\
\hline NDF (\%) & 31.09 & 35.00 & 35.85 & 37.05 & 36.78 & 38.51 & 36.82 & 40.70 \\
\hline NFC $(\%)$ & 40.03 & 37.68 & 33.62 & 36.73 & 35.10 & 34.89 & 35.14 & 33.50 \\
\hline NFC : NDF & 1.29 & 1.08 & 0.94 & 0.99 & 0.95 & 0.91 & 0.95 & 0.82 \\
\hline $\mathrm{CP}(\%)$ & 16.02 & 16.37 & 16.81 & 14.28 & 14.99 & 16.85 & 14.61 & 13.54 \\
\hline TMR pH & 5.03 & 5.04 & 5.30 & 5.46 & 5.59 & 5.13 & 5.38 & 5.25 \\
\hline abBC $\left(\right.$ meq $\left.\cdot 1^{-1}\right)$ & 3.71 & 3.44 & 4.07 & 3.62 & 3.51 & 3.99 & 4.43 & 3.36 \\
\hline $\mathrm{BVI}^{2}$ & 7.417 & 9.487 & 50.695 & 66.050 & 68.343 & 26.667 & 59.199 & 44.438 \\
\hline Rumen fluid pH & $6.29 \pm 0.41^{2}$ & $6.19 \pm 0.20$ & $6.39 \pm 0.44$ & $6.37 \pm 0.51$ & $6.31 \pm 0.19$ & $6.38 \pm 0.25$ & $6.35 \pm 0.29$ & $6.37 \pm 0.45$ \\
\hline
\end{tabular}

${ }^{1} \mathrm{ADF}$ - acid detergent fibre, NDF - neutral detergent fibre, CP- crude protein, NFC - non-fibre carbohydrate, abBC analyzed acid-base buffering capacity, BVI - analyzed dietary buffer value index, ${ }^{2} \mathrm{x} \pm \mathrm{SD},{ }^{3} \mathrm{~A}-\mathrm{H}-$ total mixed rations

Table 4. Coefficient of correlation between rumen fluid $\mathrm{pH}$ and other indicators related to diets for dairy cows

\begin{tabular}{lccccccc}
\hline & $\mathrm{abBC}^{3}\left(\mathrm{meq} \cdot \mathrm{l}^{-1}\right)$ & $\mathrm{BVI}^{4}$ & $\mathrm{ADF}^{5}(\%)$ & $\mathrm{NDF}^{6}(\%)$ & $\mathrm{NFC}^{7}(\%)$ & $\mathrm{NFC}: \mathrm{NDF}$ & $\mathrm{CP}^{8}(\%)$ \\
\hline Rumen fluid $\mathrm{pH}$ & $0.428^{1}$ & 0.578 & 0.538 & 0.522 & -0.642 & -0.582 & -0.223 \\
$P$ value $^{2}$ & 0.2897 & 0.1337 & 0.1692 & 0.1844 & 0.0858 & 0.1299 & 0.5953 \\
\hline
\end{tabular}

${ }^{1}$ Coefficient of correlation, ${ }^{2}$ Probability, ${ }^{3} \mathrm{abBC}$ - analyzed acid-base buffering capacity, ${ }^{4} \mathrm{BVI}$ - analyzed dietary buffer value index, ${ }^{5} \mathrm{ADF}$ - acid detergent fibre, ${ }^{6} \mathrm{NDF}$ - neutral detergent fibre, ${ }^{7} \mathrm{NFC}$ - non-fibre carbohydrate,

${ }^{8} \mathrm{CP}$ - crude protein

and ruminal fluid $\mathrm{pH}(0.578)$. However, no significant $(P>0.05)$ correlation was found between ruminal fluid $\mathrm{pH}$ and dietary components (Table 4$)$.

\section{Discussion}

Variations in experimental procedures and methods of expressing $\mathrm{BC}$ make it difficult to compare the results of this study with other reports of feed $\mathrm{pH}$ and $\mathrm{BC}$. The $\mathrm{BC}$ of fermented feeds was variable, depending on the composition of the plant substrate fermented. Fermented feedstuffs had quite low initial $\mathrm{pH}$ values as already found by $\mathrm{Le}$ Ruyet et al. (1992) and Giger-Riverdin et al. (2002). It must be noted that such low $\mathrm{pH}$ is necessary in order to conserve these feedstuffs. Jasaitis et al. (1987) suggested that evaluation of the $\mathrm{pH}$ and $\mathrm{BC}$ of the diet be used to predict the need for supplementing the diet with buffers to control acid-base balance of the rumen. Silage acids are neutralized by the cow's own saliva or by supplementary buffers in the ration. The $\mathrm{pH}$ has traditionally been used to evaluate the quality of fermentation in silages. The $\mathrm{pH}$ of an ensiled sample is a measure of its acidity, but is also affected by the buffering capacity of the plant. Two samples may have the same $\mathrm{pH}$ but different concentrations of acids. Active acidity $(\mathrm{pH})$ of silage extracts ranged from 3.59 to 4.14. Sebastian et al. (1996) who analysed silages from high moisture corn, detected higher values of $\mathrm{pH}(4.0-4.3)$.

Results of the second experiment showed that the defined method of determination of buffering capacity could be an adequate alternative for evaluation of silages. The basebuffering capacity for our use is defined as the milli-equivalents of base $(1 \mathrm{~N} \mathrm{NaOH})$ necessary to titrate the $\mathrm{pH}$ of a silage sample to 7. Analyzed buffer value index was calculated from individual measurements of $\mathrm{pH}$ and base-BC. Titration acidity of the water extract corresponding usually with fermentation acid concentration is a significant indicator of the quality of the fermentation process (Doležal 2008). Our results did not show a very strong relationship between the AWE value and the content of lactic acid. The correlation between the AWE value and the content of lactic acid in DM of silages was significantly lower $(r=0.487)$ than between the base-BC or BVI values. 
Tucker et al. (1992) reported that BVI could be used to evaluate the $\mathrm{pH}$ and BC of either the diet or the ruminal fluid. Because ruminal acid production from fermentation of carbohydrates varies so much, ruminants have highly developed systems to maintain ruminal pH within a physiological range of about 5.5-7.0 (Oetzel 2007). It seems better to measure buffering capacity within the range 5-7. Rumen $\mathrm{pH}$ represents the net balance between carbohydrate digestion, VFA absorption and use and buffer production (Beckman and Weiss 2005).

Miller et al. (1993) studied the influence of dietary BVI on the ruminal environment of cows consuming diets with various BVI by altering the ratio of dietary concentrate to sorghum silage. Ruminal fluid acid-base status was not affected significantly by dietary BVI.

In conclusion, in the present study no significant correlation was found between ruminal $\mathrm{pH}$ and dietary BVI. These results confirmed that dietary acid-base status alone is not adequate as a predictor of the need for buffers in the diet of lactating cows.

\section{Acknowledgements}

This work was supported by the Ministry of Education of the Slovak Republic (research project VEGA No.1/0626/08).

\section{References}

AOAC Associatition of Official Analytical Chemists Interntional 2001: Official Methods of Analysis. $17^{\text {th }}$ ed. Horwitz W. (ed): AOAC Inc., Arlington, USA

Beckman JL, Weiss WP 2005: Nutrient digestibility of diets with different fiber to starch ratios when fed to lactating dairy cows. J Dairy Sci 88: 1015-1023

Doležal P, Zeman L, Skládanka J 2008: Effect of supplementation of chemical preservative on fermentation process of lupine silage. Slovak J Anim Sci 41: 30-38

Giger-Reverdin S, Duvaux-Ponter C, Sauvant D, Martin O, Prado IN, Muller R 2002: Intrinsic buffering capacity of feedstuffs. Anim Feed Sci Technol 96: 83-102

Jasaitis DK, Wohlt JE, Evans JI 1987: Influence of fed ion content on buffering capacity of ruminant feedstuffs in vitro. J Dairy Sci 70: $1391-1403$

Le Ruyet P, Tucker WB, Hogue JF, Aslam M, Lema M 1992: Influence of dietary fiber and buffer value index on the ruminal milieu of lactating dairy cows. J Dairy Sci 75: 2394-2408

Miller TP, Tucker WB, Lema M, Shin IS, Hogue JF, Adams GD 1993: Influence of dietary buffer value index on the ruminal milieu of lactating dairy cows fed sorghum silage and grain. J Dairy Sci 76: 3571-3579

Moharrery A 2007: The determination of buffering capacity of some ruminant's feedstuffs and their cumulative effects on TMR ration. Am J Anim Vet Sci 2: 72-78

NRC (National Research Council) 2001: Nutrient requirements of dairy cattle. 7th rev. ed. National Academy Press, Washington, DC

Oetzel GR 2007: Subacute ruminal acidosis in dairy herds: physiology, pathophysiology, milk fat responses, and nutritional management. 40th Annual Conference, American Association of Bovine Practitioners, Vancouver, BC, Canada. pp. 89-119

Sebastian S, Phillip LE, Fellner V, Idziak ES 1996: Comparative assessment of bacterial inoculation and propionic acid treatment on aerobic stability and microbial populations of ensiled high moisture ear corn. J Anim Sci 74: 447-456

Tucker WB, Hogue JF, Aslam M, Lema M, Martin M, Owens FN, Shin IS, LeRuyet P, Adams GD 1992: A buffer value index to evaluate effects of buffers on ruminal milieu in cows fed high or low concentrate, silage, or hay diets. J Dairy Sci 75: 811-819

Van Soest PJ, Robertson JB, Lewis BA 1991: Methods for dietary fiber, neutral detergent fiber and non-starch polysaccharides in relation to animal nutrition. J Dairy Sci 74: 3583-3597 